\title{
The Egyptians in Sydney
}

\section{Stephanie Ho}

\section{Paul Ashton}

Although Egyptians are generally known to be a non-migrating people closely tied to their land, the late 1950s and 1960s saw waves of Egyptians leaving their homeland for Europe, North America and Australia. Migration to Australia was limited prior to this period. In 1933, there were only 500 Egyptian-born people recorded as living in Australia. This number jumped to 8,000 in 1954 and 22,000 by 1966. Today there are around 34,000 Egyptian-born people in Australia and approximately 16,500 of them (nearly 50 per cent) live in Sydney. ${ }^{1}$

Around three-quarters of Egyptian migrants settled in Australia before 1976. However, there were substantial numbers of 'recent arrivals' (accounting for almost 15 per cent of this group) in 1986-91. Most of these later migrants came under the family reunion scheme. Generally the Egyptian community is a highly educated one, with qualification levels that exceed those of the average Australian. Today many Egyptian migrants living in Sydney belong to the professional and managerial classes. ${ }^{2}$

\section{Religion and community}

In the initial years of migration, a large number of Egyptians arriving in Sydney, and elsewhere in Australia, were of Greek or Armenian background (around 36 per cent) or Italian and Maltese heritage (about 45 per cent). Egyptian Jews, Coptic Christians and Protestants each accounted for about 5 per cent of the Egyptian population, and 'a handful' were Egyptian Muslims. ${ }^{3}$ The number of Coptic Christians migrating to Sydney increased after the mid1960s, and Egyptian Muslims only began to arrive in significant numbers in the 1970s. Most Christian Egyptians who migrated to Australia in the 1950s and 1960s left Egypt in response to the 'pan-Arabist' and 'pan-Islamic' policies that gained prominence during the period of President Nasser's leadership. ${ }^{4}$

Thus the majority of Egyptian migrants are Christians. In the 1991 Australian census, 84 per cent identified with the Christian faith and only 7 per cent with Islam. ${ }^{5}$ This is in contrast to Egypt where 90 per cent of the population is Muslim.

Religion is a critical factor for Sydney's Egyptian communities. Although the Coptic Orthodox faith is not the numerically dominant religion, the Coptic Church plays an important role as a local community facilitator and a contact with Egypt.

\section{The Coptic Church}

Before the 1960s, there was scant organisation within the Egyptian community. But this changed during the mid-1960s with the increasing number of Egyptian, especially Coptic, migrants. In July 1967 the Coptic Orthodox Society was established at the initiative of Amin Salib who became its first president. The society's role was to assist Coptic families and individuals find accommodation, obtain jobs, learn English and purchase cars. The first 
groups of Coptic families met on Sunday afternoons at the Church of England parish in Artarmon and were dependent on their sister Orthodox churches for the use of their churches and halls for services and activities. ${ }^{6}$

One of the goals of the society was to lobby for the establishment of a Coptic Church in Australia. Thus in 1967, a letter was sent to the Coptic Pope, His Holiness Pope Kyrillos VI, requesting that a church be established and a priest be sent to serve the community in Sydney. On 10 March 1968, Deacon Edward was ordained priest at Saint Mark's Cathedral in Alexandria in Egypt, and given the name Father Mina. He was appointed to oversee the establishment of a church in Australia, and arrived in Australia in January 1969. He performed his first Coptic wedding ceremony in Sydney on 26 January 1969, in a converted Salvation Army hall in Redfern. ${ }^{7}$

Although based in Sydney, Father Mina regularly travelled to Melbourne to celebrate the Mass and to conduct Bible studies and Sunday school lessons. He also obtained an authority from the Department of Immigration to sponsor prospective migrants to Australia, and operated as a leader of the community. As he recalled,

People would come by the hundreds every week. I helped them to find accommodation, schooling and employment. In those days jobs were very easy to find, so families were able to settle within a few days. It was a hard start but it had to be done. ${ }^{8}$

The first Coptic Church, St Mary and St Mina's, was established in a formerly Methodist church in Railway Road, Sydenham, purchased with community funds in 1969-70. ${ }^{9}$ Since then, the Coptic Church has grown substantially. In 1982, the Pope Shenouda III College for Theological Studies was established in Sydney as the first Coptic Theological College established outside Egypt. By 1991, there were 10 Coptic Orthodox Churches in Sydney. ${ }^{10}$ Besides providing religious services, the Church serves as a hub of cultural pursuits and social support networks. In addition, the Australian Coptic Association links to Copts around the world through various community newspapers and bulletins. ${ }^{11}$ St Mary and St Mina's church was badly affected by aircraft noise, and moved to Bexley in 2001. ${ }^{12}$

\section{Arab connections}

While Muslims now account for less than 20 per cent of the Egyptian community in Sydney, most Egyptian Australians are Arab in origin and identify themselves with the wider Arab and Islamic community. The establishment of the Australian Federation of Islamic Councils in 1965 and the subsequent growth around the Imam Ali mosque in Lakemba and the Al-Zahra mosque in Arncliffe have also deepened the connection between Egyptians and Muslims from other parts of the Middle East. ${ }^{13}$

Christian and Muslim Egyptian communities in Sydney share a common heritage and identification with Egypt, and relations between the two have been mainly tolerant and peaceful. Although different organisations and associations minister to these communities, efforts have been made to bring these Egyptian associations together. One of these has been the Australian Egyptian Council Forum. It was established in 1994 and is based in Sydney. Its objectives are to work towards a better understanding of all Egyptian associations, position 
the Egyptian community within the greater Australian society, to represent Egyptian community interests in dealing with the government and to encourage young people to keep in touch with their Egyptian heritage.

Stephanie Ho is a Singaporean public historian who has recently completed a PhD at the University of Technology, Sydney

Paul Ashton is Associate Professor of Public History and Co-Director of the Australian Centre for Public History at the University of Technology, Sydney

\section{References}

Anthony Ham, 'Egyptians', in James Jupp, (ed), The Australian People: An Encyclopaedia of the Nation, Its People and Their Origins, Cambridge University Press, Cambridge UK, 2001

Coptic Orthodox Church website, http://www.coptic.org.au/, accessed 24 November 2008

\section{Endnotes}

${ }^{1}$ ABS 2006 Census; Anthony Ham, 'Egyptians', in James Jupp, (ed), The Australian People: An Encyclopaedia of the Nation, Its People and Their Origins, Cambridge University Press, Cambridge UK, 2001, p 274

${ }^{2}$ Anthony Ham, 'Egyptians', in James Jupp, (ed), The Australian People: An Encyclopaedia of the Nation, Its People and Their Origins, Cambridge University Press, Cambridge UK, 2001, p 275

${ }^{3}$ Bureau of Immigration, Multicultural and Population Research, Community Profiles -1991 Census Egypt Born, 1995, p 3

${ }^{4}$ M Girgis, 'Egyptians and Sudanese', James Jupp (ed), The Australian People, Angus and Robertson, Sydney, 1988, p 366

${ }^{5}$ Bureau of Immigration, Multicultural and Population Research, Community Profiles -1991 Census Egypt Born, 1995, p 3

${ }^{6}$ M Attia, Coptic Orthodox Church of Australia 1969-1994, COPT, Sydney, 1995

${ }^{7}$ Sunday Telegraph, 26 Jan 1969

${ }^{8}$ Quoted in M Attia, Coptic Orthodox Church of Australia 1969-1994, COPT, Sydney, 1995,

p 15

${ }^{9}$ Coptic Orthodox Church website, http://www.coptic.org.au/, accessed 24 November 2008

${ }^{10}$ Bureau of Immigration, Multicultural and Population Research, Community Profiles - 1991 Census - Egypt Born, 1995, p 4

${ }^{11}$ Anthony Ham, 'Egyptians', in James Jupp, (ed), The Australian People: An Encyclopaedia of the Nation, Its People and Their Origins, Cambridge University Press, Cambridge UK, 2001, p 275

${ }^{12}$ St Mary and St Mina's Coptic Orthodox Church website, http://www.stmary.org.au/Our_church/our_church.htm, accessed 24 November 2008

${ }^{13}$ Anthony Ham, 'Egyptians', in James Jupp, (ed), The Australian People: An Encyclopaedia of the Nation, Its People and Their Origins, Cambridge University Press, 2001, p 275 